\title{
Widespread expression of intestinal markers in gastric carcinoma: a light and electron microscopic study using BD-5 monoclonal antibody
}

\author{
R FIOCCA, ${ }^{*}$ LAURA VILLANI, ${ }^{*}$ PATRIZIA TENTI,** M CORNAGGIA, $\dagger$ \\ GIOVANNA FINZI, $\dagger$ C CAPELLA, $\dagger$ MARIA PRAT, $\uparrow$ G BUSSOLATI, $\uparrow$ E SOLCIA
}

From the *IRCCS Policlinico San Matteo, Pavia, the †Multizonal Hospital, Varese, the $\ddagger$ Department of Human Pathology, University of Pavia, and the $\lceil$ Department of Biomedical Sciences and Oncology, University of Turin, Italy

SUMMARY BD-5 monoclonal antibody reacted with tumour cells in 262 of 316 cases of gastric cancers, including 121 of 134 early, 141 of 182 advanced tumours $(p<0.01$ ), and 113 of 146 o glandular, 72 of 83 diffuse, 22 of 25 mucoid, and 55 of 59 mixed tumours. No difference in reactivitywas observed between metastatic and non-metastatic advanced tumours. Immunocytochemical techniques applied to light and electron microscopical specimens of colorectal mucosa and gastrico cancer showed that BD-5 immunoreactive material occurred in the Golgi complex, in small clear, to dense cored, cytoplasmic vesicles, and in the glycocalix of the luminal and lateral membranes of normal and neoplastic cells in the glands, as well as in the peripheral membrane of dispersed $0^{\circ}$ neoplastic cells. Mucin granules stored in the cytoplasm of goblet cells were unreactive or poorly reactive. Ultrastructural features consistent with colorectal type differentiation were observed ino many reactive tumours. Unreactive tumours showing ultrastructural patterns consistent withs intestinal differentiation, especially of small bowel type, were also observed.

Signs of intestinal differentiation, including BD-5 immunoreactivity, often occur in gastric cancer, irrespective of histological type and stage of disease.

"Intestinal-type differentiation" was described many decades ago in gastric cancer. ${ }^{1-4}$ It has always been believed that this type of metaplastic differentiation was typical of adenocarcinomas, or "intestinal" cancers, while diffuse cancers originate from non-metaplastic gastric mucosa. ${ }^{256}$ Recently, however, ultrastructural and cytochemical markers of intestinal epithelia have been detected in gastric cancers of both glandular and diffuse type. ${ }^{7-9}$

In a previous study the BD-5 monoclonal antibody was obtained after immunisation against the human gastric carcinoma line KATO III. ${ }^{10}$ The antibody precipitated a high molecular weight sulphated glycoprotein and reacted with epithelial cells of normal and neoplastic human intestine but not with many other epithelial structures, including the gastric mucosa - with the exception of some foci of intestinal metaplasia. ${ }^{10}$ Many gastric carcinomas tested (12 of 16), however, showed extensive expression of the BD-5

Accepted for publication 5 August 1987 reactive antigen.

In this paper BD-5 reactive cells and cytoplasmic structures of the human gut were investigated by both light and electron microscopy to validate the antibody as a probe for differentiation of intestinal type. The 3 antibody was used to identify and characterise intestinal type growths in a large series of gastric cancers of $\supsetneq$ early and advanced, metastatic, and non-metastatico types, representing all the main histological patterns known to occur in such tumours. ${ }^{9-11}$

\section{Material and methods}

Specimens of rectal, colonic, ileal, jejunal, duodenal, N pyloric, or fundic mucosa, apparently free of disease, $\sigma$ were obtained endoscopically or at operation from $10<$ adults aged between 31 and 58 years. For light microscopical examination, the specimens were fixed in formol-acetate solution and embedded in paraffin ${ }_{0}$ for 24 to 48 hours; for electron microscopical examination, they were fixed for two hours at $4^{\circ} \mathrm{C}$ in formalde- $\mathbb{\Phi}$ hyde-glutaraldehyde solution in $0 \cdot 1 \mathrm{M}$ phosphate $\frac{O}{\mathbb{D}}$ 
buffer ( $\mathrm{pH} 7 \cdot 3$ ), embedded in Lowicryl or fixed for one hour in 1\% osmium tetroxide and embedded in Eponaraldite mixture. ${ }^{912}$ Samples of malignant tissue (six from each case) and benign mucosa taken at operation from 316 cases of gastric carcinoma ${ }^{11}$ were processed in the same way. Both early cancers, restricted to the mucosa or submucosa, and advanced cancers, invading the muscularis propria with or without serosal disease, were divided into four main histological types: glandular, diffuse, mucoid, and mixed-based on previously described criteria. ${ }^{911} 1314$

\section{HISTOCHEMICAL STUDIES}

Paraffin sections of malignant and benign tissue were stained with hematoxylin and eosin, alcian blue $(1 \%$, pH 2.5) and periodic acid Schiff (AB-PAS), and high iron diamine (HID) for sulphomucins. ${ }^{15}$ They were also stained with an indirect immunohistochemical technique using the hybridoma supernatant containing BD-5 monoclonal antibodies, ${ }^{10}$ followed by peroxidase conjugated rabbit immunoglobulins (Ig) directed against mouse Ig (Dako, Copenhagen), or by biotinylated horse Ig directed against mouse Ig (Vector Laboratories, Burlingame), and the avidin-biotin complex (Vector) according to the method of Hsu et al. ${ }^{16}$ All antibodies were diluted $1 / 40$ in $0.15 \mathrm{M}$ Tris buffered-saline (TBS), $\mathrm{pH} 7 \cdot 3$, added to $5 \%$ nonimmune pooled human serum to prevent nonspecific binding of antibodies to the sections. For comparison, immunohistochemical tests with pepsinogen II (PG II) polyclonal antibodies were performed, as previously reported." Control tests using antigen adsorbed antibodies were also performed to ensure specificity of BD-5 or PG II immunostaining. ${ }^{1011}$

For each tumour (with the exception of mixed tumours) BD-5 immunoreactive cells were scored as follows: a score of $1=$ less than $1 \%$ of BD-5 reactive cells; a score of $2=1$ to $10 \%$; a score of $3=10$ to $40 \%$; a score of $4=$ more than $40 \%$; a score of $0=$ no or only occasional reactive cells.

\section{ULTRASTR UCTURAL STUDIES}

Ultrathin sections of tumour and mucosal samples fixed in aldehyde and embedded in osmium EponAraldite were stained with uranyl acetate and lead citrate for electron microscopical examination. In some cases adjacent semithin $(0 \cdot 8 \mu \mathrm{m})$ sections were deplasticised with sodium hydroxide, deosmicated with sodium metaperiodate, and immunostained with BD-5 antibodies as above. ${ }^{17}$ Ultrathin sections of specimens embedded in Lowicryl were incubated overnight with BD-5 antibodies, followed by gold tagged goat antimouse Ig polyclonal antibodies (EY Laboratories San Mateo, California), and uranyl-lead counterstaining. ${ }^{12} 18$ Incubation of BD-5 antibodies with the supernatant from KATO III cell cultures, containing the BD-5 antigen, prevented immunostaining.

\section{Results}

DISTRIBUTION OF BD-5 IMMUNOREACTIVITY IN BENIGN GASTROINTESTINAL EPITHELIA

In accordance with previous studies, ${ }^{10} \mathrm{BD}-5$ immunoreactivity was detected in most epithelial colorectal mucosa cells and in a few epithelial cells the ileum and jejunum. Luminal surfaces, subapical cytoplasm, Golgi complex, and lateral membranes reacted most commonly (figs la-c). In a few cells both the supranuclear and infranuclear cytoplasm showed reactivity. The mucin granules of goblet cells were unreactive or stained faintly. The immunogold technique applied to electron microscopical specimens of colorectal mucosa showed BD-5 reactive material in some Golgi cisternae, as well as in Golgi-derived small, clear to dense cored, vesicles scattered in the supranuclear cytoplasm and concentrated in the subapical cytoplasm. In addition, the immunoreactivity was localised in the surface coat covering the luminal microvilli and in the glycocalix adhering to some lateral membranes (fig 2).

No staining was observed in healthy duodenum and stomach. Some of the areas of intestinal metaplasia found in benign gastric mucosa from patients with cancer showed BD-5 immunoreactivity, especially in deep, less well differentiated crypts (fig 1d).

No obvious association was noted between BD-5 reactivity and the morphological type-(complete type I, incomplete types II A and B, or "enterocolic"1920 —of metaplasia). Non-goblet columnar cells producing neutral (type II A metaplasia) or sulphated mucin (type II B metaplasia) were unreactive. Dysplastic lesions, especially those in areas of intestinal metaplasia, were often reactive with BD-5 (fig 1e).

\section{BD- 5 IMMUNOREACTIVITY IN GASTRIC CANCERS} BD-5 immunoreactive cells were detected in 262 of 316 gastric cancers, including 121 of 134 early cancers, 60 of 69 intramucosal, and 61 of 65 submucosal tumours; in 141 of 182 advanced cancers; as well as in 113 glandular, 72 diffuse, 22 mucoid, and 55 mixed cancers (table 1). In keeping with these figures, the mean score of immunoreactive cells was lower in glandular cancers $(2 \cdot 00)$ compared with diffuse $(2 \cdot 76)$ and mucoid $(2 \cdot 84)$ cancers. Take the group of advanced tumours alone, the lower of BD-5 immunoreactivity among adenocarcinomas 53 of 57 , score 1.61) compared with diffuse ( 31 of 40 , score $2 \cdot 55$ ), and mucoid cancers 18 of 21 , score $2 \cdot 81$ ) became slightly more pronounced. A higher prevalence of BD-5 immunoreactivity was observed among early cancers of glandular, diffuse, 


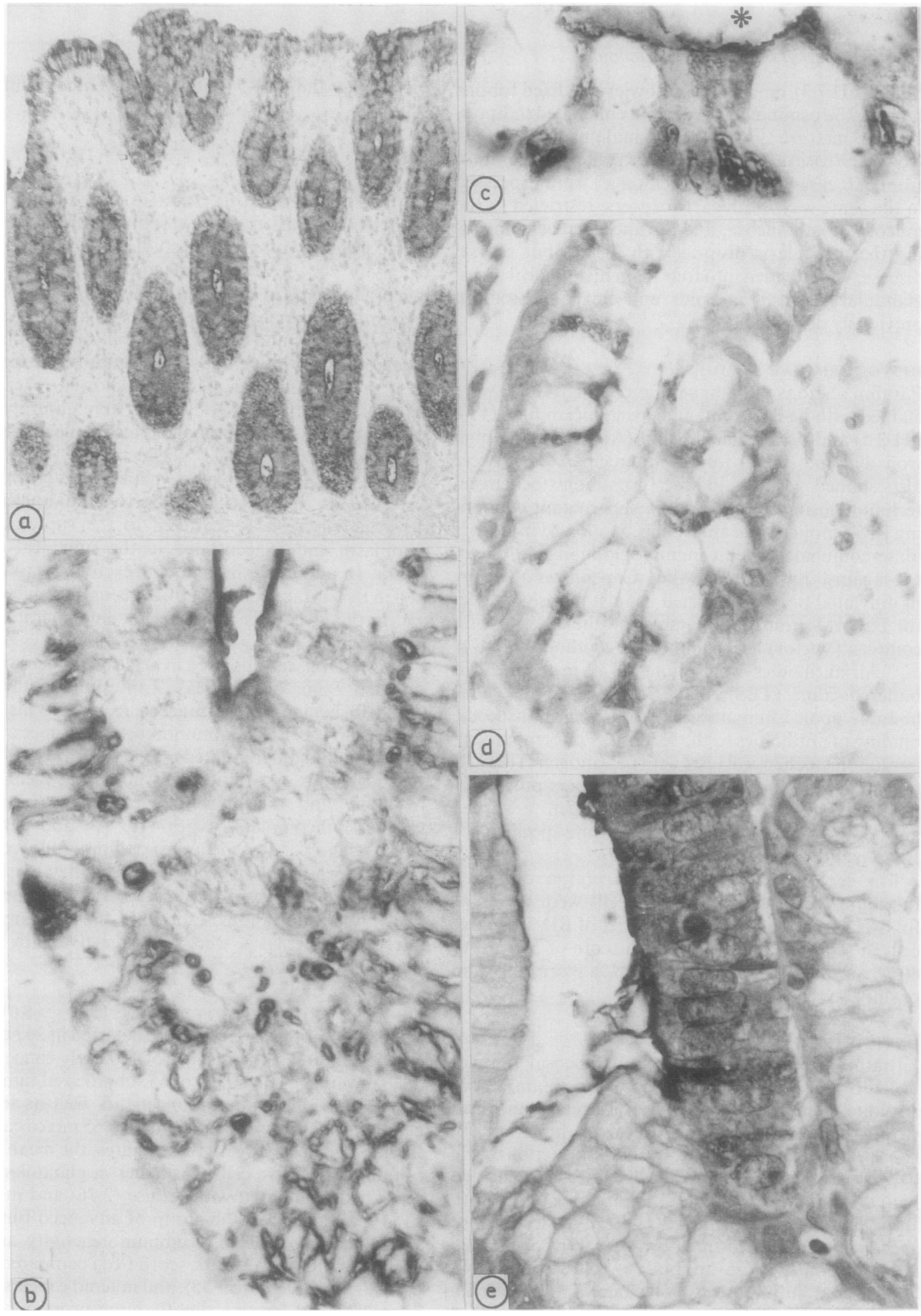

Fig 1 BD-5 immunoreactivity of colonic mucosa. (a) Note reactivity of luminal surface, supranuclear Golgi and lateral membranes in deep gland, (b) luminal surface $\left({ }^{*}\right)$, Golgi complex, and supranuclear cytoplasm of columnar cells in (c) epithelium of upper gland showing unreactivity of goblet cell thecae. (d) Scattered reactivity of supranuclear cytoplasm is $\stackrel{\mathbb{D}}{\square}$ observed in deep part of intestinal-type metaplastic gland of stomach, $(e)$ while luminal and cytoplasmic reactivity is found in dysplastic focus arising in incomplete (type II B) intestinal metaplasia. (Immunoperoxidase-haematoxylin.) 


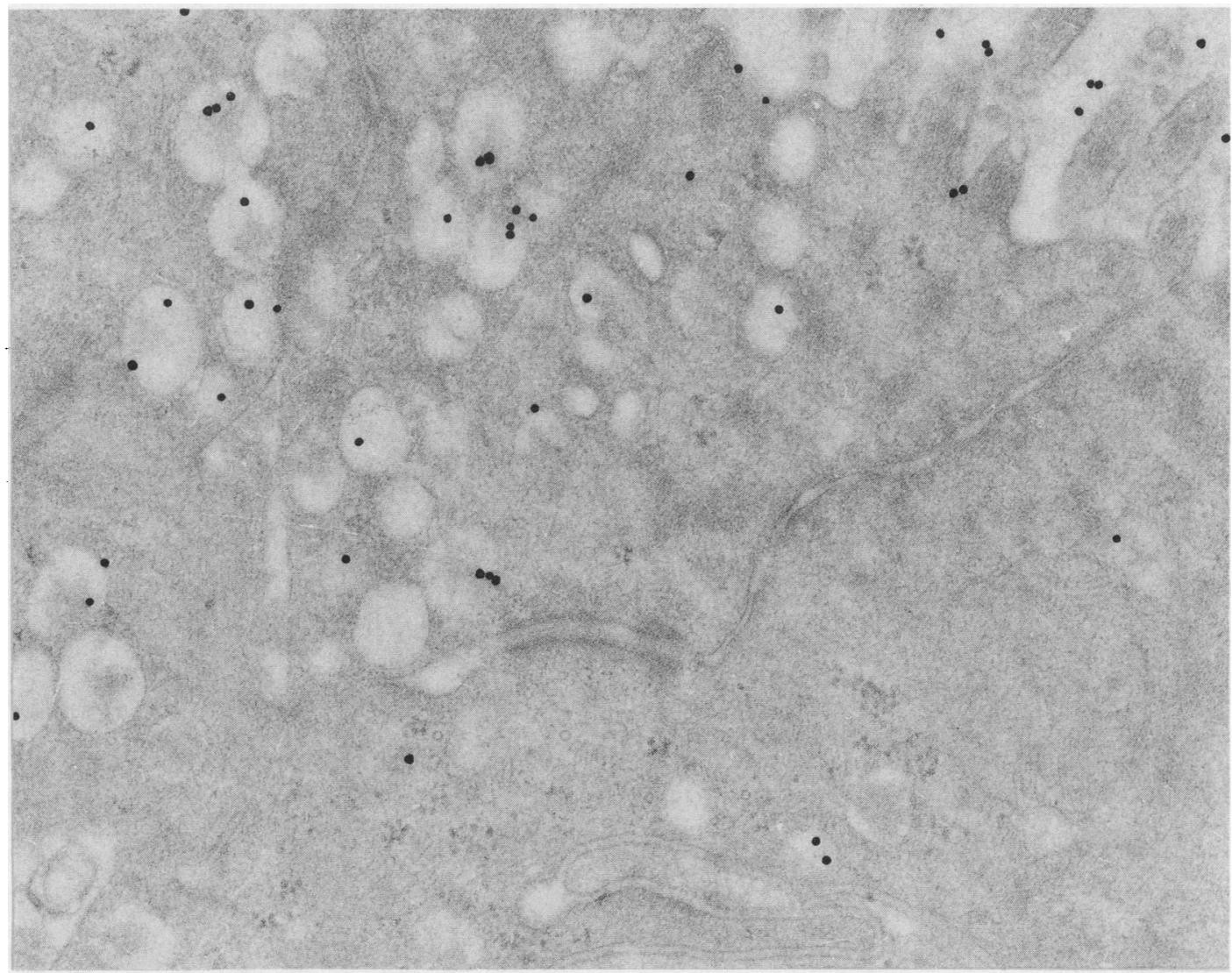

Fig 2 Immunocytochemical detection of BD-5 reactivity in clear or dense cored, small, subapical vesicles and surface coat adhering to luminal microvilli. Note some of vesicles contact luminal membrane or lateral interdigitating membrane (bottom). (Immunogold technique, uranyl-lead staining.)

and mucoid type $(90.5 \%)$ compared with advanced cancers $(73.9 \%, \mathrm{p}<0.01)$.

No consistent difference was observed between metastatic and non-metastatic tumours, despite a slight trend for a higher prevalence of BD-5 in nonmetastatic advanced tumours of glandular and diffuse type ( 23 of 30 cases, $77 \%$ ) compared with metastatic tumours (61 of 87 cases, $70 \%$ ) (table 2 ).

Two ultrastructurally confirmed parietal cell carcin- omas $^{21}$ and one small to intermediate cell undifferentiated carcinoma failed to react with the BD-5 antibody.

HISTOLOGICAL, HISTOCHEMICAL, AND CYTOLOGIC CHARACTERISATION OF THE BD-5 REACTIVE COMPONENT IN GASTRIC CANCERS BD-5 reactive cells of glandular tumours generally formed tubules, solid trabeculae, or pseudoglands

Table 1 BD5 expression among gastric cancers of different histological type and stage

\begin{tabular}{|c|c|c|c|c|c|c|}
\hline \multirow[b]{2}{*}{ Histology (\%) } & \multicolumn{2}{|l|}{ Early cancers } & \multicolumn{2}{|c|}{ Advanced cancers } & \multicolumn{2}{|l|}{ Total } \\
\hline & $B D-5(\%)$ & Score & $B D-5(\%)$ & Score & $B D-5(\%)$ & Score \\
\hline $\begin{array}{l}\text { Glandular (46.2) } \\
\text { Diffuse }(26 \cdot 3) \\
\text { Mucoid (7.9) } \\
\text { Mixed }(18 \cdot 7) \\
\text { Other }(0 \cdot 9) \\
\text { Total }(100 \cdot 0)\end{array}$ & $\begin{array}{c}60 / 69(87 \cdot 0) \\
41 / 43(95 \cdot 3) \\
4 / 4(100) \\
16 / 18(88 \cdot 9) \\
121 / 134(90 \cdot 3)\end{array}$ & $\begin{array}{l}2.43 \\
2.95 \\
3.00\end{array}$ & $\begin{array}{l}53 / 77(68 \cdot 8) \\
31 / 40(77 \cdot 5) \\
18 / 21(85 \cdot 7) \\
39 / 41(95 \cdot 1) \\
0 / 3 \\
141 / 182(77 \cdot 5)\end{array}$ & $\begin{array}{l}1.61 \\
2.55 \\
2.81\end{array}$ & $\begin{array}{c}113 / 146(77 \cdot 4) \\
72 / 83(86 \cdot 7) \\
22 / 25(88 \cdot 0) \\
55 / 59(93.2) \\
0 / 3 \\
262 / 316(82.0)\end{array}$ & $\begin{array}{l}2 \cdot 0 \\
2 \cdot 76 \\
2 \cdot 84\end{array}$ \\
\hline Total $(100 \cdot 0)$ & $121 / 134(90 \cdot 3)$ & $2 \cdot 65^{*}$ & $141 / 182(77 \cdot 5)$ & $2 \cdot 02^{*}$ & $262 / 316(82 \cdot 9)$ & $2 \cdot 30^{*}$ \\
\hline
\end{tabular}

"“Mixed" and "other" tumours excluded. 


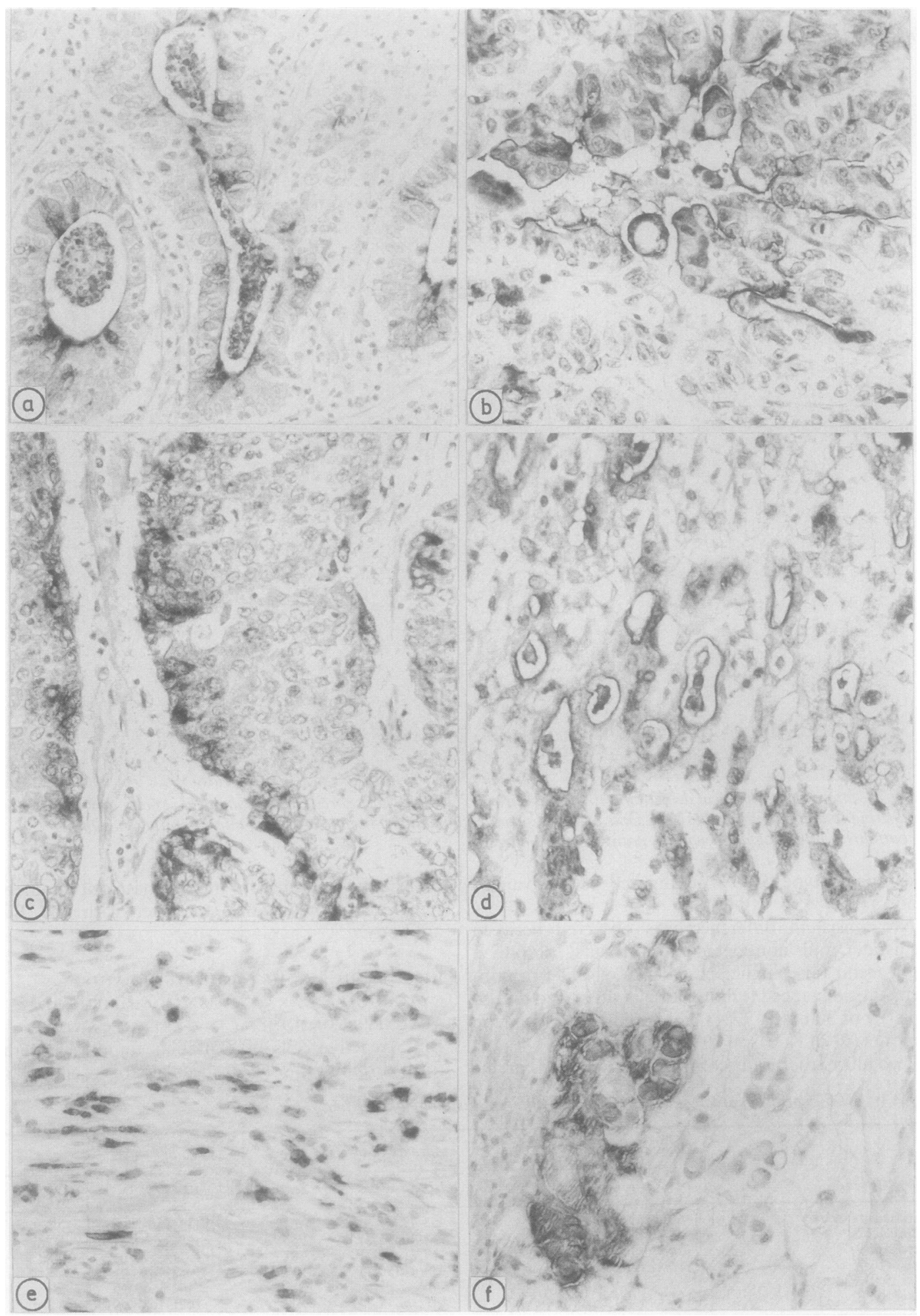

Fig 3 Intracellular or luminal BD-5 reactivity of tubular (a), papillary (b), and solid (c) subtypes of glandular cancers and $(d)$ of microglandular subtype of diffuse cancer; ( $e$ ) scattered and stripe forming reactive cells of diffuse cancer (desmoplastic subtype; and $(f)$ small focus of reactive cells near to unreactive mucin lake of a mucoid cancer (Immunoperoxidase-haematoxylin.) 


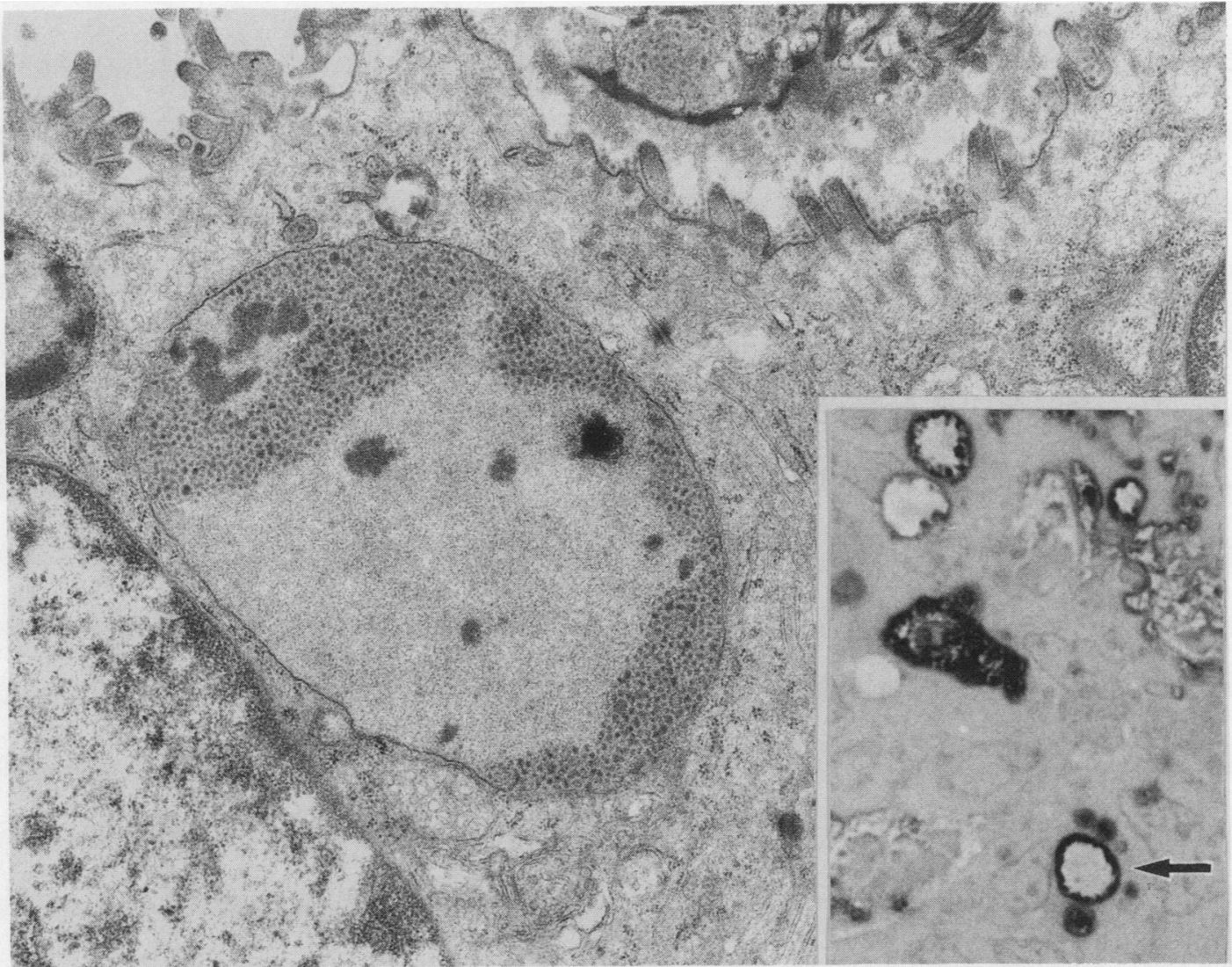

Fig 4 Ultrastructure of $B D-5$ reactive microglandular cancer showing irregular microvilli with cytoplasmic rootlets and adhering glycocaliceal bodies, as well as large cytoplasmic $R$-body storing particles resembling glycocaliceal bodies. Note BD-5 reactivity of luminal surface (arrow) and cytoplasmic $R$-bodies in consecutive $800 \mathrm{~nm}$ section. (Uranyllead).

with occasional microcysts and papillae (figs $3 a-c)$. In diffuse tumours they presented as scattered cells, small irregular cell clusters, stripes one cell thick, or microglands with barely evident lumina (figs $3 \mathrm{~d}$ and $\mathrm{e}$ ). In mucoid tumours the cells formed glands and bands bordering mucin lakes, or floated within these as round, often signet ring cells (fig $3 \mathrm{f}$ ). The reactivity of mixed tumours affected their mucoid, glandular, and diffuse components but not the squamous component, which was present in only six of 59 cases, all advanced stage. BD-5 reactivity was usually found at the luminal surface of glands, microglands, and intracellular microcysts. The lateral membranes of some cells in glandular or solid structures, as well as the peripheral membranes of some dispersed cells were also reactive. The intensity and extent of cytoplasmic staining were

Table 2 Association between BD5 expression and metastases in 182 cases of advanced cancer

\begin{tabular}{|c|c|c|c|c|}
\hline \multirow[b]{2}{*}{ Histology } & \multicolumn{2}{|l|}{ Metastatic } & \multicolumn{2}{|c|}{ Non-metastatic } \\
\hline & $\overline{B D-5(\%)}$ & Score & $\overline{B D-5(\%)}$ & Score \\
\hline $\begin{array}{l}\text { Glandular } \\
\text { Diffuse } \\
\text { Mucoid } \\
\text { Mixed } \\
\text { Other }\end{array}$ & $\begin{array}{l}35 / 52(67 \cdot 3) \\
26 / 35(74 \cdot 3) \\
16 / 17(94 \cdot 1) \\
33 / 35(94 \cdot 3) \\
0 / 3\end{array}$ & $\begin{array}{l}1.50 \\
2.37 \\
3.06\end{array}$ & $\begin{array}{c}18 / 25(72 \cdot 0) \\
5 / 5(100) \\
2 / 4(50) \\
6 / 6(100)\end{array}$ & $\begin{array}{l}1.84 \\
3.80 \\
1.75\end{array}$ \\
\hline Total & $110 / 142(77 \cdot 5)$ & $1.99^{*}$ & $31 / 40(77 \cdot 5)$ & $2 \cdot 12^{*}$ \\
\hline
\end{tabular}

"“Mixed" and "other" tumours excluded. 


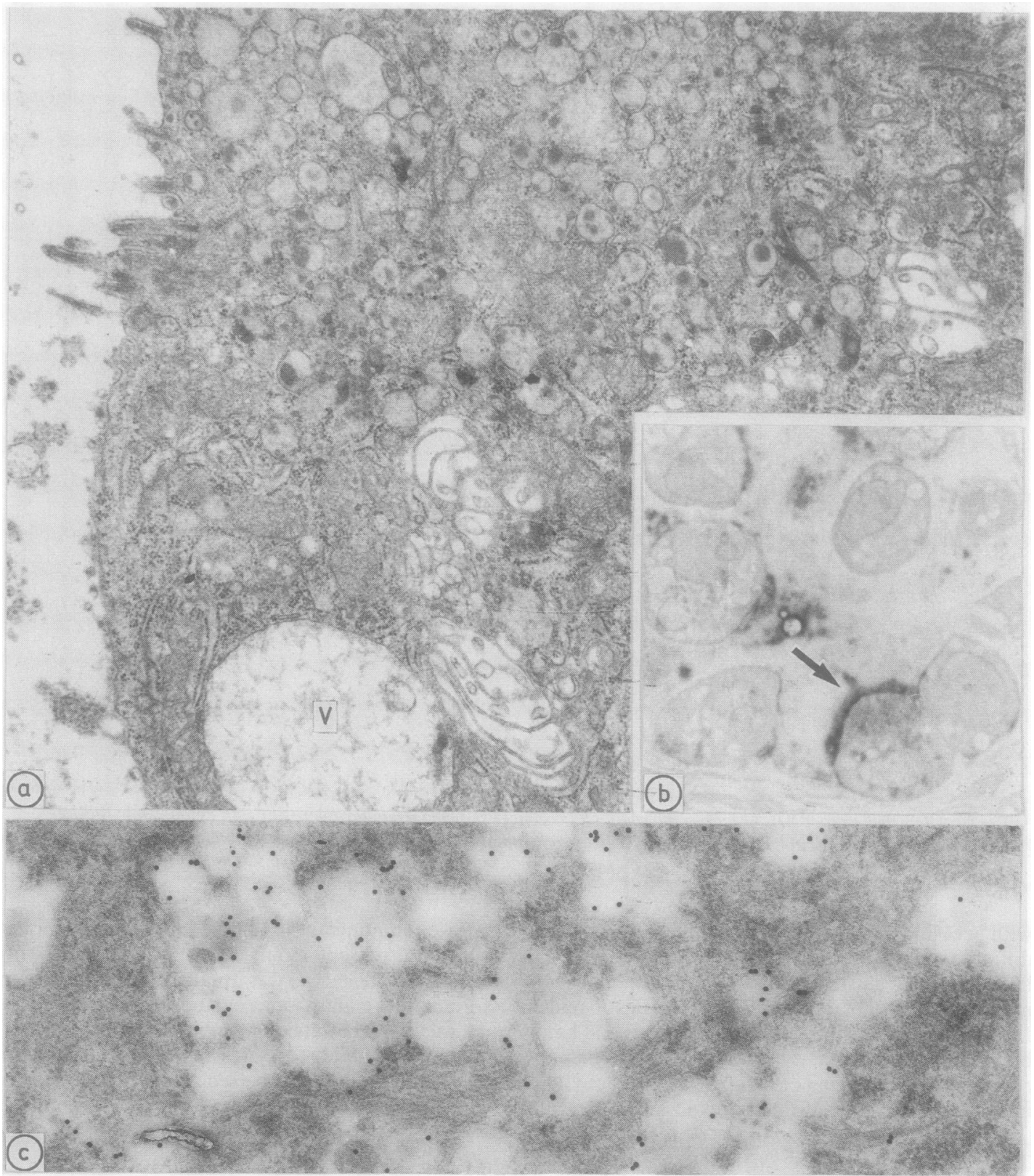

Fig 5 (a) Rooted microvilli, glycocaliceal bodies, small, clear, and dense cored vesicles in tumour cell of mucoid cancer (b) showing surface and cytoplasmic BD-5 reactivity (arrow) in consecutive section, where many unreactive vacuoles of dilated reticulum are also seen. Vesicles in another tumour cell of the same case show intense reactivity with-BD-5 antibody.

also extremely variable: no staining at all to faint staining of the Golgi area or the juxtaluminal cytoplasm to intense staining of the whole cytoplasm. Intracellular and extracellular mucins were poorly reactive or unreactive.

Most BD-5 reactive cells and structures, especially those of the luminal surfaces and subapical cytoplasm, showed slight alcianophilia when stained with the $\mathrm{AB}-\stackrel{?}{\rightarrow}$ PAS technique; some cells showed slight HID reac- 0 tivity. Both these techniques stained heavily the intracellular and extracellular mucins. In serial tumour sections BD-5 and PG II immunoreactivities, $\mathbb{\mathbb { D }}$ 
though often coexisting in the same tumour, were found in separate cells, usually in distinct areas or foci. Moreover, increased BD-5 expression occurred in PG II unreactive tumours.

Ultrastructural investigation of BD-5 reactive tumours, including thin sections adjacent to BD-5 immunostained semithin sections, showed tumour cells bearing irregular microvilli with long cytoplasmic roots in most cases, or, especially in mucoid cancers and advanced diffuse cancers of signet ring cell subtype, clear mucin granules of goblet cell type, which are normally found in the intestinal crypts. ${ }^{22} 23$ In addition, glycocaliceal bodies, cytoplasmic Rbodies, small vesicles or osmiophilic dense bodies resembling those reported in colorectal epithelium and associated tumours ${ }^{24-29}$ were often observed (figs 4 and $5 \mathrm{a}$ and $\mathrm{b}$ ). With the immunogold technique, BD-5 reactive material was seen in the small vesicles and dense bodies, the surface coat of luminal microvilli, and the glycocalix adhering to the lateral membranes of adenocarcinomatous cells, or to peripheral membranes of dispersed cells (fig 5c). Intestinal-type tumour granules that were unreactive with BD-5 were also found. They generally showed a predominance of columnar cells with rooted microvilli, without glycaliceal bodies, R-bodies, and small apical vesicles or dense bodies, thus mimicking "immature absorptive cells" or "principal crypt cells" of the small intestine. ${ }^{22} 23$ Admixed goblet cells were occasionally found. Cells showing foveolar-type punctate granules or solid to target-like mucopeptic granules 9 failed to react with BD-5 antibodies.

\section{Discussion}

In this investigation the previously reported reactivity of the BD-5 monoclonal antibody with intestinal epithelia, ${ }^{10}$ particularly in the large and lower small intestine, and its failure to react with normal gastric epithelia, have been confirmed. Immunocytochemical studies at light and electron microscopy level showed that there were sites of BD-5 immunoreactivity in the luminal surface coat, Golgi complex of intestinal cells, as well as in the glycocalix adhering to their lateral surface and in a system of small, clear to dense cored vesicles linking the Golgi with luminal and lateral membranes. Thus the BD-5 antibody can be regarded as a reliable, cytologically defined intestinal marker.

As reported, BD-5 immunoreactive cells have been detected in 262 of $316(83 \%)$ of a large series of gastric carcinomas, being widely represented in all the main histological types and stages of the disease. In accordance with several histochemical and ultrastructural studies, ${ }^{7-9} 3031$ and in contrast with widely held beliefs, ${ }^{25}$ it has been clearly shown that intestinal-type cells and associated markers are not restricted to adenocarcin- oma. In fact, diffuse, mucoid, and mixed type cancers also showed strong expression of the BD-5 intestinal marker, while parallel electron microscopical studies confirmed the presence of more or less prominent signs of intestinal differentiation in all BD-5 reactive tumours investigated, irrespective of their histological classification.

In mucoid cancers the mucoid component of mixed cancers, and some signet ring cells of diffuse cancers goblet cell differentiation has already been shown by mucin histochemical and electron microscopical studies. $^{793032}$ The BD-5 reactive antigen, which is expressed in most colorectal and some jejuno-ileal goblet cells, is also expressed in some immature, transitional, and absorptive cells of colorectal and ileo-jejunal mucosa, and seems to differentiate more gastric cancers ( $83 \%$ of our series) than specific goblet cell markers such as the M3 glycopeptide, found by Bara et al in $35 \%$ of their cases.'

The BD-5 immunoreactivity of weakly alcianophilic luminal surfaces, even in the absence of mucin production, is especially useful for the identification of microlumina and intracellular microcysts in the microglandular subtype of diffuse cancer and in the medullary (solid) subtype of glandular cancer, and for recognising the intestinal nature of some adenocarcinoma lacking both goblet cells and a striated luminal border. The cytoplasmic or membrane staining of some apparently immature cells of trabecular, solid, or diffuse growths may also be helpful in this respect.

Electron microscopic immunogold staining showed the association between intracellular reactivity and small, clear to dense cored vesicles originating in the Golgi area, concentrated in the subapical cytoplasm of gland forming columnar cells or scattered in the peripheral cytoplasm of round, dispersed cells. Similar vesicles have already been described in normal colorectal epithelium and associated growths, ${ }^{242933}$ as well as in some intestinal-type gastric cancers. ${ }^{9}$

The frequent observation of glycocaliceal bodies, cytoplasmic R-bodies, and small vesicles or dense bodies in BD- 5 reactive tumour cells emphasises the consistent occurrence of colorectal-type differentiation in gastric cancer. This has already been supported by histochemical ${ }^{34} 35$ and ultrastructural studies. ${ }^{9}$ Intestinal-type growths that do not react with BD-5 usually show rooted microvilli without glycocaliceal bodies, $\mathrm{R}$-bodies, or small vesicles, and thus tend to resemble small intestinal epithelium, have also been observed. The occurrence of ultrastructural, enzymatic, mucin and antigenic markers of small intestine in gastric carcinoma, particularly columnar absorptive cells, has been well documented. ${ }^{3489} 30313438$

The reason why intestinal-type differentiation occurs so often in gastric carcinoma is unknown. The fact that some of the intestinal markers expressed in 
gastric cancer are also expressed in embryonal, fetal, or neonatal gastric epithelium, ${ }^{4142}$ coupled with the common occurrence of intestinal metaplasia in chronically inflamed and malignant gastric mucosa, ${ }^{204344}$ might be of help in explaining the behaviour of gastric tumour cells.

Notably, some sulphomucin producing columnar cells of type II B intestinal metaplasia ${ }^{20}$ and of some intramucosal cancers ${ }^{9}$ failed to react with BD-5 antibodies, a finding that, coupled with their lack of the M3C sulphoglycopeptide antigen (specific for colorectal goblet cells), ${ }^{38}$ suggests that such cells are not associated with sulphomucin producing colorectal cells but with gastric foveolar or superficial cells. This is confirmed by their storage of the M1 antigen. ${ }^{38} 40$

No overlapping has been observed in malignant and benign tissues between BD-5 immunoreactive cells and cells immunoreactive for PG II, a selective marker of gastroduodenal mucopeptic cells expressed by $47 \%$ of the gastric cancers reported here." The two types of immunoreactive cells coexisted in 116 of the 316 tumours. PG II, which was not expressed, as much as BD-5, showed better defined histological and stage related changes, which, unlike those of BD-5, might be of prognostic value. ${ }^{11}$ In glandular and diffuse cancers PG II indeed seems to work as a marker for increased invasive and metastatic potential."

In conclusion, the glycoprotein detected by the BD5 monoclonal antibody represents one of the most widely expressed antigens in gastric cancer. It is also an effective marker of some intestinal-type tumour cells lines, particularly those mimicking colorectal cells or crypt cells of the lower small intestine. In conjunction with structural and histochemical markers labelling other tumour cell lines, such as mucopeptic and foveolar cells, or absorptive and goblet cells of the small bowel, ${ }^{347-911353640}$ the BD-5 antibody may be of help in reconstructing the natural history of this tumour.

The work was partly supported by grants from the Italian National Research Council (N 8000583 44, PF Oncologia; N $860051604 \mathrm{G}$ Gastroenterologia; N 8601476 57, PF TBMS), the Health and Education Ministry, and the AIRC Foundation (Milan).

\section{References}

1 Masson P. Les tumeurs. In: Sergent E, Ribadeau-Dumas L, Barbonneix $\mathrm{L}$, eds. Traité de pathologie médicale et de thérapeutique appliquée. Vol XXVII. Paris: Maloine A et Fils, 1923:1-64.

2 Lauren $P$. The two histological main types of gastric carcinoma diffuse and so-called intestinal-type carcinoma. Acta Pathol Microbiol Scand 65;64:31-49.

3 Goldman H, Ming SC. Fine structure of intestinal metaplasia and adenocarcinoma of the human stomach. Lab Invest 1968;18:203-10.
4 Goldman H, Ming SC. Mucins in normal and neoplastic epith- $\stackrel{0}{\stackrel{0}{二}}$ elium: histochemical distribution. Archives of Pathology 으 1968;85:580-6.

5 Nagayo T, Komagoe T. Histological studies of gastric mucosal $\overrightarrow{\vec{F}}$ cancer with special reference to relationship of histological $\stackrel{\mathscr{S}}{\rightarrow}$ pictures between the mucosal cancer and the cancer-bearing 0 gastric mucosa. Gann 1961;52:109-19.

6 Nakamura K, Sugano H, Takagi K. Carcinoma of the stomach in $\overline{\bar{\omega}}$ incipient phase: its histogenesis and histological appearances. $\vec{\nabla}$ Gann 1968;59:251-8.

7 Bara J, Hamelin L, Martin E, Burtin P. Intestinal M3 antigen, a 仓 marker for the intestinal type differentiation of gastric carcinomas. Int J Cancer 1981;28:711-9.

8 Furihata C, Tatematsu M, Miki K, et al. Gastric and intestinaltype properties of human gastric cancers transplanted into nude $\vec{\omega}$ mice. Cancer Res 1984;44:727-33.

9 Fiocca R, Villani L, Tenti P, et al. Characterization of four main $\overrightarrow{7}$ cell types in gastric cancer: foveolar, mucopeptic, intestinal columnar and goblet cells. An histopathologic, histochemical $\stackrel{\oplus}{\longrightarrow}$ and ultrastructural study of "early" and "advanced" tumours. iv Path Res Pract 1987;182:308-25.

10 Prat M, Rossino P, Bussolati G, Morra I, Comoglio PM. Production of monoclonal antibodies for the immunohisto- 0 chemical detection of gastric carcinomas. Cancer Detect Prev 1987;10:293-301.

11 Fiocca R, Cornaggia M, Villani L, Capella C, Solcia E, Samloff $\mathbb{C}^{1}$ IM. Expression of pepsinogen II by gastric cancer. Relationship $\frac{D}{2}$ to local invasion and lymph node metastases. Cancer 1988;61:100-6.

12 Roth J, Bendayan M, Carlemalm E, Villiger W, Garavito $M$. Enhancement of structural preservation and immunocyto- $\vec{E}$ chemical staining in low temperature embedded pancreatic $\infty$ tissue. J Histochem Cytochem 1981;29:663-71.

13 Kubo T. Histologic appearance of gastric carcinoma in high and low mortality countries: comparison between Kyushu, Japan and Minnesota, USA. Cancer 1971;28:726-34.

14 Ishii T, Ikegami N, Hosoda Y, Koide O, Kaneko M. The biological behaviour of gastric cancer. J Pathol 1981;134: 응 97-115.

15 Spicer SS. Diamine methods for differentiating mucosubstances histochemically. J Histochem Cytochem 1965;13:211-34.

16 Hsu S-M, Raine L, Fanger H. Use of avidin-biotin-peroxidase complex $(\mathrm{ABC})$ in immunoperoxidase techniques. $\mathrm{J}$ Histochem Cytochem 1981;29:577-80.

17 Fiocca R, Sessa F, Tenti P, Usellini L, Capella C, O'Have MMT, Solcia E. Pancreatic polypeptide (PP) cells in the PP-rich lobe of $\frac{\cap}{0}$ the human pancreas are identified ultrastructurally and $\bar{\sigma}$ immunocytochemically as F cells. Histochemistry 1983;77: 511-23.

18 Cornaggia M, Riva C, Capella C, Solcia E, Samloff IM. Subcellular localisation of pepsinogen II in stomach and duodenum by the immunogold technique. Gastroenterology 1987;92:
585-93.

19 Heilmann KL, Höpker WW. Loss of differentiation in intestinal metaplasia in cancerous stomachs. A comparative morphologic 을. study. Path Res Pract 1979;164:244-58.

20 Jass JR. Role of intestinal metaplasia in the histogenesis of gastric $\mathcal{N}$ carcinoma. J Clin Pathol 1980;33:801-10.

21 Capella C, Frigerio B, Cornaggia M, Solcia E, Pinzon-Trujillo Y, 용 Chejfec G. Gastric parietal cell carcinoma-a newly recognised $\mathrm{\omega}$ entity: light microscopic and ultrastructural features. Histopathology 1984;8:813-24.

22 Trier JS, Rubin CE. Electron microscopy of the small intestine: a review. Gastroenterology 1965;49:574-603.

23 Toner PG. Cytology of intestinal epithelial cells. Int Rev Cytol 1968;24:233-43.

24 Kaye GI, Fenoglio CM, Pascal RR, Lane N. Comparative electron microscopic features of normal, hyperplastic, and $\frac{\pi}{\mathbb{D}}$ adenomatous human colonic epithelium. Gastroenterology 1973;64:926-45. 
25 Biempica L, Sternlieb I, Sohn HB, Ali M. R-Bodies of human rectal epithelial cells. Arch Pathol Lab Med 1976;100:78-80.

26 Stone J, Mukherjee M, Hecker R. C Bodies and R bodies in the epithelial cell of normal and diseased human rectum. Arch Pathol Lab Med 1977;101:437-41.

27 Marcus PB, Martin JH, Green RH, Krouse MA. Glycocalyceal bodies and microvillous core rootlets. Arch Pathol Lab Med 1979;103:89-92.

28 Hickey WF, Seiler MW. Ultrastructural markers of colonic adenocarcinoma. Cancer 1981;47:140-5.

29 Mughal S, Filipe MI, Jass JR. A comparative ultrastructural study of hyperplastic and adenomatous polyps, incidental and in association with colorectal cancer. Cancer 1981;48:2746-55.

30 Sasano N, Nakamura K, Arai M, Akazaki K. Ultrastructural cell patterns in human gastric carcinoma compared with nonneoplastic gastric mucosa. Histogenetic analysis of carcinoma by mucin histochemistry. JNCI 1969;43:783-802.

31 Nevalainen T, Järvi $\mathrm{OH}$. Ultrastructure of intestinal and diffuse type gastric carcinoma. J Pathol 1977;122:129-36.

32 Rapp W, Windisch M, Peshke P, Wurster K. Purification of human intestinal goblet cell antigen (GOA1), its immunohistological demonstration in the intestine and mucus producing gastrointestinal adenocarcinomas. Virchows Arch (Path Anat) 1979;382:163-77.

33 Shamsuddin AM, Phelps PC, Trump BF. Human large intestinal epithelium: light microscopy, histochemistry and ultrastructure. Hum Pathol 1982;13:790-803.

34 Abe M, Ohuchi N, Sakano H. Enzyme histo- and biochemistry of intestinalized gastric mucosa. Acta Histochem Cytochem 1974;7:282-8.

35 Ma J, De Boer WGRM, Nayman J. Intestinal mucinous substan- ces in gastric intestinal metaplasia and carcinoma studied by immunofluorescence. Cancer 1982;49:1664-7.

36 Wattenberg LW. Histochemical study of aminopeptidase in metaplasia and carcinoma of the stomach. Archives of Pathology 1959;67:281-6.

37 Lauren P. Histochemical study of enzyme distribution in diffuse and intestinal-type gastric carcinoma. Acta Pathol Microbiol Scand (Suppl) 1967;187:62.

38 Nardelli J, Bara J, Rosa B, Burtin P. Intestinal metaplasia and carcinomas of the human stomach: an immunohistological study. J Histochem Cytochem 1983;31:366-75.

39 Bara J, Loisillier F, Burtin P. Antigens of gastric and intestinal mucous cells in human colonic tumours. $\mathrm{Br} J$ Cancer 1980;41:209-21.

40 Fiocca R, Villani L, Cornaggia M, Capella C, Bara J, Solcia E. Foveolar-superficial cells in gastric cancer. (in press).

41 Häkkinen IPT, Järvi O, Gironroos J. Sulphoglycoprotein antigens in human alimentary canal and gastric cancer. An immunohistochemical study. Int J Cancer 1968;3:572-81.

42 De Boer WGRM, Forsyth A, Nairn RC. Gastric antigens in health and disease. Behaviour in early development, senescence, metaplasia and cancer. Br Med J 1969;3:93-4.

43 Jârvi $O$, Laurén $P$. On the role of heterotopias of the intestinal epithelium in the pathogenesis of gastric cancer. Acta Pathol Microbiol Scand 1951;29:26-43.

44 Morson BC. Carcinoma arising from areas of intestinal metaplasia in the gastric mucosa. Br J Cancer 1955;9:377-85.

Requests for reprints to: Professor Enrico Solcia, Istituto Anatomia Patologica, Via Forlanini 16, 27100 Pavia, Italy. 